\title{
Methylation status of DDIT3 gene in Chronic Myeloid Leukemia
}

Ya-li Wang', Jun Qian*1, Jiang Lin', Dong-ming Yao', Zhen Qian', Zhao-hui Zhu' and Jian-yong Li²

\begin{abstract}
Background: DNA-damage-inducible transcript 3 (DD/T3), a candidate tumor suppressor gene (TSG), has been found involved in the regulation of cellular growth and differentiation. The epigenetic changes of TSGs are recently recognized as an abnormal mechanism contributing to the development of chronic myeloid leukemia (CML). The aim of this study was to investigate the methylation status of DDIT3 gene in CML patients.

Methods: The methylation status of DDIT3 promoter was detected in the bone marrow mononuclear cells from 53 patients with CML using methylation-specific PCR (MSP). The expression levels of DDIT3 and bcr/ab/ transcript were determined by real-time quantitative PCR (RQ-PCR). Clinical data of these patients were collected and analyzed.

Results: The aberrant methylation of DDIT3 gene promoter was found in 35 of 53 (66\%) CML cases. Correlation was not found between DDIT3 promoter hypermethylation and the age, sex, hemoglobin concentration, platelet counts, chromosomal abnormalities, bcr/ab/ transcript, and staging of CML patients $(P>0.05)$, but found between DDIT3 promoter hypermethylation and WBC counts of CML cases $(R=0.781, P<0.001)$. The level of DDIT3 transcript in $C M L$ patients was significantly lower than that in controls (median 3.28 vs $19.69, P<0.001$ ), however, there was no difference in the level of DDIT3 transcript between methylation-positive CML cases (0.05-65.32, median 2.13) and methylationnegative CML cases (0.12-126.04, median 3.92) $(P>0.05)$.
\end{abstract}

Conclusion: Our results demonstrate that aberrant methylation of DDIT3 occurs in CML frequently.

\section{Background}

Chronic myeloid leukemia (CML) is a stem cell disease characterized by excessive accumulation of clonal myeloid cells in hematopoietic tissues. Almost all patients with CML present the common cytogenetic abnormality of the $t(9 ; 22)$ and the $b c r / a b l$ fusion gene which is generated by the translocation. Clinically CML can be divided into three phases: the chronic phase $(\mathrm{CP})$, the accelerated phase (AP), the blast crisis (BC) $[1,2] . \mathrm{BC}$ is the last stage of CML disease progress, in which hematopoietic differentiation become arrested and immature blasts accumulate in the bone marrow and spill into the circulation. The mechanisms responsible for transition of $\mathrm{CP}$ into $\mathrm{BC}$ remain poorly understood [3].

In the pathogenesis of leukemias and other cancers, gene silencing by aberrant DNA methylation is a frequent event $[4,5]$. The methylation of several tumor suppressor

* Correspondence: qianjun0007@hotmail.com

1 Department of Hematology, Affiliated People's Hospital of Jiangsu University, Zhenjiang, Jiangsu, 212002, PR China

Full list of author information is available at the end of the article genes (TSGs) including E-cadherin, death-associated protein kinase $(D A P K)$, estrogen receptor $(E R)$, and the cell cycle regulating genes ( $P 15^{I N K 4 B}$ and $P 16^{I N K 4 A}$ ), has been confirmed associated with the development and progression of CML [6-9].

DNA-damage-inducible transcript 3 (DDIT3), also named CCAAT/enhancer binding protein zeta $(C / E B P \zeta)$, is expressed ubiquitously and can be induced by a wide variety of treatments such as DNA lesion, hypoglycaemia, radiation and cellular stress. Several studies have confirmed the role of DDIT3 in the regulation of cellular growth and differentiation [10-13]. The overexpression of DDIT3 transcript has been found to induce increased apoptosis of myeloid cells and block cells in the progression from G1 to S phase $[14,15]$. The level of DDIT3 transcript has been revealed down-regulated in myeloid malignancies in our previous study [16]. The other five members of C/EBP proteins also play important roles in cellular proliferation and terminal differentiation of hematopoietic cells. Recently, two members of $C / E B P$ family, $C / E B P \alpha$ and $C / E B P \delta$, have been found to be 
silenced by aberrant methylation in acute myeloid leukemia (AML) [17-19]. However, the methylation status of DDIT3 promoter has not yet been studied in leukemia. The primary aim of this study is to investigate the methylation status of DDIT3 promoter in CML patients and determine the association of DDIT3 methylation with the patients' clinical features.

\section{Materials and methods Patients and samples}

Fifty-three cases of CML seen at the Affiliated People's Hospital of Jiangsu University were selected for this study based on the availability of stored leukemic cells. Thirtyfive patients were in CP, three in AP, and fifteen in BC. The diagnosis of $\mathrm{CP}, \mathrm{AP}$ and $\mathrm{BC}$ was established according to conventional criteria. Briefly, $\mathrm{CP}$ was defined as having within the peripheral blood and bone marrow less than $10 \%$ blasts, less than $20 \%$ basophils, and less than $30 \%$ blasts plus promyelocytes, with $t(9: 22)$ translocation or $b c r / a b l$ transcript. AP was defined as having blasts $\geq$ $10 \%$, blasts and promyelocytes $\geq 30 \%$, basophils $\geq 20 \%$, platelets $\leq 100 \times 10^{9} / \mathrm{L}$ unrelated to therapy, or cytogenetic clonal evolution. $\mathrm{BC}$ was defined as the presence of $\geq 20 \%$ peripheral or bone marrow (BM) blasts, or extramedullary blastic disease. The BM samples from all patients were harvested at the time of diagnosis and BM mononuclear cells (BMNCs) were isolated using Ficoll solution and washed twice in PBS and then frozen in $80^{\circ} \mathrm{C}$. BM samples collected from thirteen donors of BM transplantation were used as controls. Placenta tissue of one healthy pregnant woman was used as the sample to prepare positive controls of methylated and unmethylated DNA. Informed consents were provided according to the Declaration of Helsinki.

\section{RNA isolation and Real-time quantitative PCR (RQ-PCR)}

Total RNA was extracted from the BMNCs of CML patients by the guanidinium thiocyanate/acid phenol method using Trizol reagent (Invitrogen Life Technologies, USA) in accordance with the manufacturer's standard method. $2 \mu \mathrm{g}$ of total RNA was reverse transcribed into cDNA by using random primers, $200 \mathrm{U}$ of MMLV reverse transcriptase (InVitrogen), $0.5 \mathrm{mM}$ dNTPs, 10 $\mathrm{mM}$ dithiothreitol, and $25 \mathrm{U}$ of RNase inhibitor (InVitrogen). $40-\mu \mathrm{L} \mathrm{RT}$ reaction was performed at $37^{\circ} \mathrm{C}$ for 60 $\mathrm{min}$, then at $95^{\circ} \mathrm{C}$ for $5 \mathrm{~min}$. cDNA was stored in $-20^{\circ} \mathrm{C}$ until assayed. DDIT3 and $b c r / a b l$ transcripts were quantified using RQ-PCR established previously $[7,16]$.

\section{DNA isolation and bisulfite modification}

DNA was isolated from BMNCs using Genomic DNA Purification Kit (Gentra, Minneapolis, MN, USA). $1 \mu \mathrm{g}$ of genomic DNA was modified as described in manufacture's instruction using the CpGenome ${ }^{\mathrm{Tm}}$ DNA Modifica- tion Kit (Chemicon, Ternecula, Canda). Modified DNA was resuspended in water and used immediately or stored at $-80^{\circ} \mathrm{C}$ until used.

\section{Methylation-specific polymerase chain reaction (MSP)}

DNA methylation status in the CPG island of DDIT3 promoter was determined by the MSP procedure described previously [20]. Primer sequences for the methylated (M) MSP reaction were 5'-GGTTCGATATTACGTCGATTTTTTAGC-3' (forward) and 5'-GCCGACATT AACCCCG-3' (reverse), and primer sequences for the unmethylated (U) MSP reaction were 5'-ATTTTTGGGTTTGATATTATGTTGATTTTTTAGTG-3' (forward) and 5'-CAAAAAA TAACACACCAACATTA ACCCCA-3' (reverse). $25 \mu \mathrm{l}$ of reaction mixture contained $1 \times$ PCR buffer (containing $15 \mathrm{mmol} / \mathrm{L} \mathrm{MgCl}_{2}$ ), 2.5 $\mathrm{mmol} / \mathrm{L}$ dNTPs, $0.4 \mathrm{pmol} / \mathrm{L}$ primers, $1 \mathrm{U}$ Hot start DNA polymerase (Takara, Tokyo, Japan), and $2 \mu \mathrm{l}$ of modified DNA. PCR conditions were $95^{\circ} \mathrm{C}$ for $5 \mathrm{~min}, 35$ cycles for $30 \mathrm{~s}$ at $94^{\circ} \mathrm{C}, 30 \mathrm{~s}$ at $63.1^{\circ} \mathrm{C}(\mathrm{M})$ or $62^{\circ} \mathrm{C}(\mathrm{U}), 30 \mathrm{~s}$ at $72^{\circ} \mathrm{C}$ followed by a final $7 \mathrm{~min}$ extension step at $72^{\circ} \mathrm{C}$. Amplification was carried out in a 9600 Perkin-Elmer Thermal Cycler (PerkinElmer Inc., Ramsey, MN, USA). Placenta DNA treated in vitro with SssI methyltransferase (New England Biolabs, Beverly, MA, USA) and untreated were used as positive controls for methylated and unmethylated templates, respectively. Negative control samples without DNA were included for each set of PCR. PCR products were analyzed on $3 \%$ agarose gels and visualized under UV illumination. To verify successful bisulfite modification of the DNA, a sequence containing cytosines would not be amplified after bisulfite modification by using primers that would only give an amplified product if the cytosines in the template sequence were not converted to uracils. For this purpose, a region of the $\beta$ actin promoter was amplified with every modified DNA sample. Samples that did not give a band were considered completely modified and further used for MSP analysis. Those cases were defined as methylation positive if their sample showed a visual band amplified with methylatedspecific primers, even if the band was faint. All positive results were confirmed in at least two MSP analyses. Using $80 \mathrm{ng}$ totally methylated placenta DNA serially diluted by totally unmethylated DNA, we determined that the sensitivity for a clear detection of a methylated allele was $2 \%$. Positive products of $\mathrm{M}$ and $\mathrm{U}$ reaction from one patient in $\mathrm{CP}$ were cloned and sequenced (Shanghai GeneCore BioTechnologies Co., Ltd., Shanghai, China).

\section{Conventional cytogenetic analysis}

Conventional cytogenetic investigation was carried out for these patients. Chromosomes were prepared routinely by the direct method or short-term culture of BM cells. Karyotypes were analyzed on R-banded meta- 


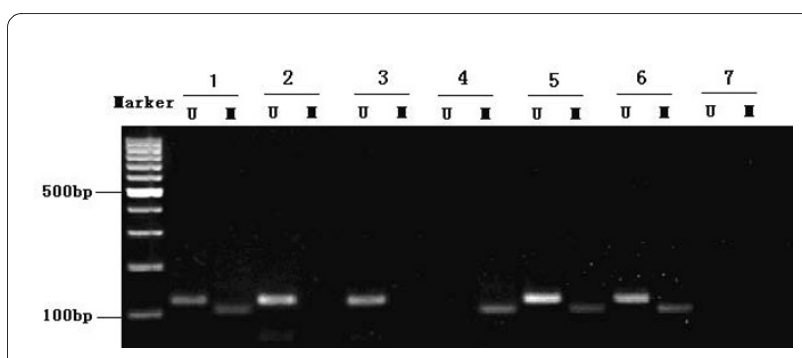

Figure 1 MSP results of DDIT3 gene in CML. $U$ and $M$ represent $P C R$ results by using primer sets for methylated and unmethylated DDIT3 gene, respectively. 1: positive control (positive controls of methylation and unmethylation are genomic DNA of placenta which is modified with or without M.Sssl); 2: sample of one BM donor; 3,4: samples of two cases at CP; 5 : sample of one case at AP; 6: sample of one case at BC; 7 : ddH2O; Mark: Gene Ruler ${ }^{\text {TM }} 100$ bp DNA Ladder.

phases. Chromosomal abnormalities were described according to the International System for Human Cytogenetic Nomenclature. CML patients were classified as three subgroups according to the types of cytogenetic abnormalities: $t(9 ; 22)$, variant $t(9 ; 22)$, and $t(9 ; 22)$ with additional alteration.

\section{Statistical analysis}

Statistical analysis was performed using the SPSS 13.0 software package (SPSS, Chicago, IL, USA). Chi-square analysis and Fisher exact test were carried out to compare the difference of frequencies between groups of patients. Mann-Whitney's U-test was carried out to the difference of age, level of DDIT3 and $b c r / a b l$ transcript between the methylated and the unmethylated groups. The correlation between the frequency of DDIT3 promoter methylation and the clinical and hematologic parameters was analyzed with Spearman's rank correlation. For all analyses, the $P$-values were two-tailed, and a $P$-value of $<0.05$ was considered statistically significant.

\section{Results and discussion}

Thirty-five patients (66\%) showed DDIT3 hypermethylation that was not found in all controls $(P<0.001)$. The representative results of MSP were shown in Fig 1 . The sequencing of PCR products from one CML patient confirmed the MSP results, shown in Fig 2. There were no significant correlations between the methylation status of DDIT3 promoter and the clinical features, such as age, sex, initial hemoglobin level, platelet counts, chromo-

\section{I :}

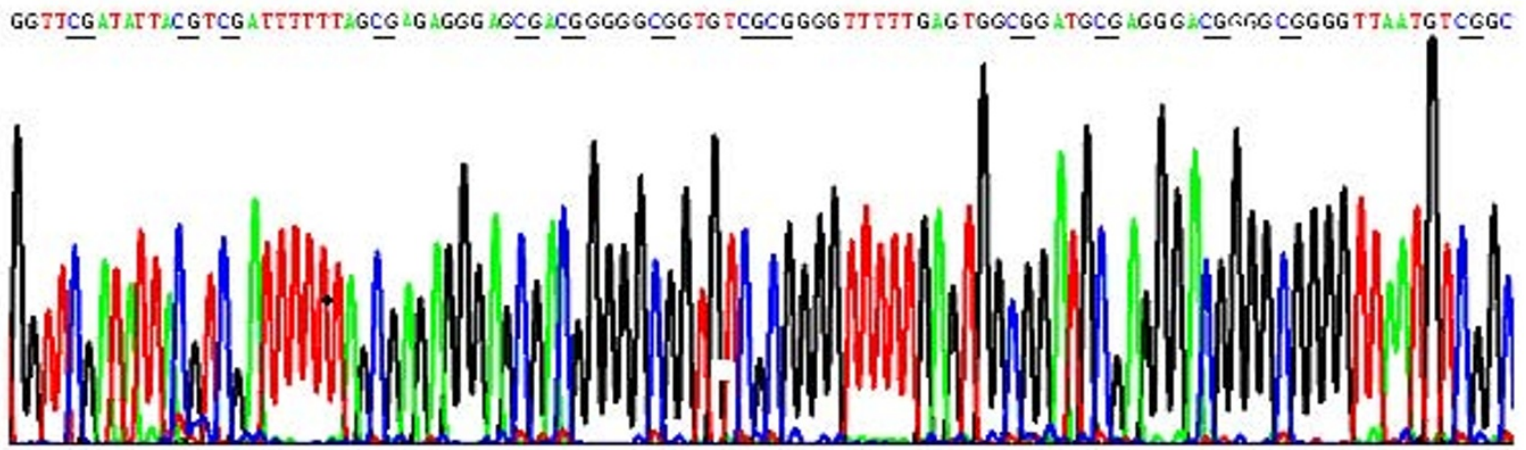

II :

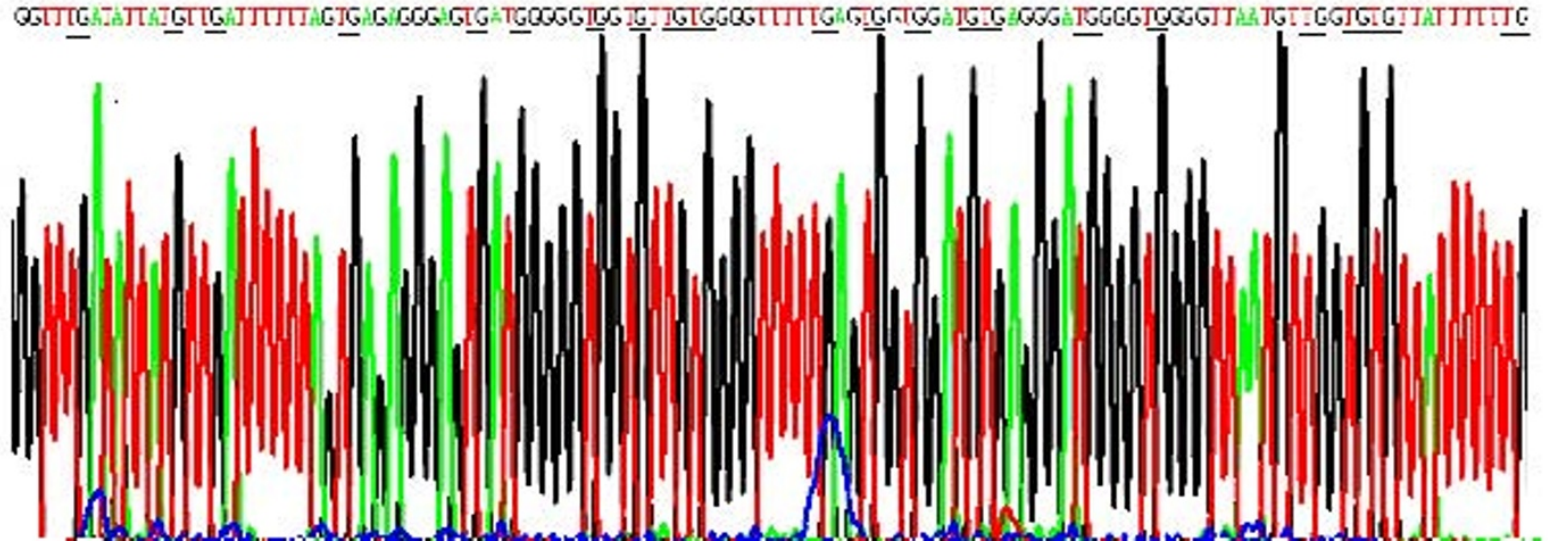


somal abnormalities, and $b c r / a b l$ transcript $(P>0.05)$. The level of DDIT3 transcripts in CML patients (0.05126.04, median 3.28) was significantly lower than that in controls (6.19-82.16, median 22.37) $(P<0.001)$. Although methylation-positive CML cases had lower DDIT3 transcript level than those methylation-negative cases, however, the difference was not significant (Table 1). This result may be associated with the low number of patients studied. Other mechanisms besides DNA methylation might be also involved in the regulation of DDIT3 expression. More cases should be further studied to determine the impact of DDIT3 methylation on the regulation of transcription.

The correlation was found between DDIT3 promoter hypermethylation and white blood cells (WBC) $(\mathrm{R}=$ $0.781, P<0.001)$. Using partial correlation analysis to exclude the effect of staging, DDIT3 promoter hypermethylation was also correlated with $\mathrm{WBC}(\mathrm{R}=-0.474, P=$ $0.001)$. WBC of patients with methylation was significantly lower than that of patients without methylation (Table 1). We postulate that the down-regulation of DDIT3 transcripts caused by promoter methylation fails to induce mitotic cessation of injured cells, which eventually results in the delivery of DNA lesions to offspring cells and the susceptibility to carcinogenesis. However, the offspring cells gaining DDIT3 methylation might be prone to apoptosis or growth inhibition owing to other mechanisms.

The frequencies of DDIT3 promoter hypermethylation in CML patients in CP, AP and BC were shown in Table 1. However, correlation was not found between the frequency of DDIT3 promoter hypermethylation and different CML stages $(P>0.05)$. Our results suggested that the methylation of DDIT3 promoter might occur in the early stage of CML development. Further study on a more number of CML patients is needed to explore the role of DDIT3 methylation in the progression of CML.

$C / E B P$ genes are believed to be critically involved in hematopoietic differentiation and leukemogenesis. Especially, the crucial role of $C / E B P \alpha$ in lineage determination during normal hematopoiesis is well established. $C / E B P \alpha$ mutations, contributing as an early event to leukemogenesis by inhibiting myeloid differentiation, are found in 10$15 \%$ of AML cases [19]. Recently, hypermethylation of $C /$ $E B P \alpha$ promoter has also been identified in $12-51 \%$ of AML cases $[18,19]$. The systematic analysis has revealed that $C / E B P \alpha$ mutations or hypermethylation are associated with favorable karyotype or prognosis $[18,19]$. Hypermethylation of another C/EBP member, $C / E B P \delta$, has been revealed in 35\% AML patients [17]. These studies indicate that epigenetic alterations of $C / E B P$ genes are

Table 1: Correlation between methylation of DDIT3 gene and the clinical characteristics of CML patients.

Status of DDIT3 methylation

\begin{tabular}{|c|c|c|c|c|}
\hline Patient's parameters & $\begin{array}{l}\text { Patients with methylated } \\
\text { DDIT3 }(\mathrm{n}=35)\end{array}$ & $\begin{array}{l}\text { Patients with unmethelated } \\
\text { DDIT3 }(\mathrm{n}=18)\end{array}$ & $\begin{array}{c}\text { Total } \\
(n=53)\end{array}$ & $P$ value \\
\hline Ages $(y r)^{1}$ & $48(21-73)$ & $40(17-83)$ & $45(17-83)$ & 0.225 \\
\hline Sex (male/female) & $28 / 7$ & $10 / 8$ & $38 / 15$ & 0.106 \\
\hline WBC $\left(\times 10^{9} / L\right)^{1}$ & $38.0(2.2-178.6)$ & $161.8(4.1-235.2)$ & $75.6(2.2-235.2)$ & 0.007 \\
\hline Hemoglobin $(\mathrm{g} / \mathrm{dL})^{1}$ & $9.9(4.9-14.8)$ & $9.3(5.2-14.3)$ & $9.5(4.9-14.8)$ & 0.963 \\
\hline Plateletcounts $\left(\times 10^{9} / \mathrm{L}\right){ }^{1}$ & $264(20-1494)$ & $263(24-870)$ & $264(20-1494)$ & 0.844 \\
\hline Cytogenetics & & & & 0.542 \\
\hline$t(9 ; 22)$ & $26(63 \%)$ & $15(37 \%)$ & 41 & \\
\hline variant $t(9 ; 22)$ & $2(100 \%)$ & $0(0 \%)$ & 2 & \\
\hline $\begin{array}{l}\mathrm{t}(9 ; 22) \text { with additional } \\
\text { alteration }\end{array}$ & $7(70 \%)$ & $3(30 \%)$ & 10 & \\
\hline Staging & & & & 0.256 \\
\hline $\mathrm{CP}$ & $24(68 \%)$ & $11(32 \%)$ & 35 & \\
\hline AP & $3(100 \%)$ & $0(0 \%)$ & 3 & \\
\hline $\mathrm{BC}$ & $8(53 \%)$ & $7(47 \%)$ & 15 & \\
\hline$b c r / a b /$ transcript & $4.82(0.28-877.94)$ & $3.37(0.26-221.77)$ & $3.96(0.26-877.94)$ & 0.583 \\
\hline DDIT3 transcript & $2.13(0.05-65.32)$ & $3.92(0.12-126.04)$ & $3.28(0.05-126.04)$ & 0.152 \\
\hline
\end{tabular}

WBC, white blood cells; CP, chronic phase; AP, accelerated phase; BC, blast crisis. ${ }^{1}$ Median (range). 
involved in leukemia and can be used for disease stratification as well as therapeutic targets.

In conclusion, we demonstrate that aberrant methylation in the CpG island of the promoter region of DDIT3 gene is a common event in CML. However, further study will be needed to determine the role of DDIT3 methylation in the development, progress, and prognosis of CML.

\section{Competing interests}

The authors declare that they have no competing interests.

\section{Authors' contributions}

QJ and LJY designed the study, analyzed the data and wrote the manuscript; WY, LJ and YDM performed all experiments; QZ and ZZH gave assistance with technical performance and contributed to the writing of the manuscript.

\section{Acknowledgements}

This study was supported by Jiangsu Province's Key Medical Talent Program (RC2007035) and Social Development Foundation of Zhenjiang (SH2006032).

\section{Author Details}

'Department of Hematology, Affiliated People's Hospital of Jiangsu University, Zhenjiang, Jiangsu, 212002, PR China and 2Department of Hematology, The First Hospital of Nanjing Medical University, Jiangsu Provincial People's Hospital, Nanjing, Jiangsu, 210029, PR China

Received: 7 April 2010 Accepted: 23 May 2010

Published: 23 May 2010

\section{References}

1. Quintás-Cardama A, Cortes JE: Chronic myeloid leukemia: diagnosis and treatment. Mayo Clin Proc 2006, 81:973-988.

2. Melo JV, Barnes DJ: Chronic myeloid leukaemia as a model of disease evolution in human cancer. Nat Rev Cancer 2007, 7:441-453.

3. Calabretta B, Perrotti D: The biology of CML blast crisis. Blood 2004 103:4010-4022

4. Baylin SB, Herman JG: DNA hypermethylation in tumorigenesis: epigenetics joins genetics. Trends Genet 2000, 16:168-174

5. Esteller M: Aberrant DNA methylation as a cancer-inducing mechanism. Annu Rev Pharmacol Toxicol 2005, 45:629-656.

6. Issa JP, Zehnbauer BA, Civin Cl, Collector MI, Sharkis SJ, Davidson NE, Kaufmann SH, Baylin SB: The estrogen receptor CpG island is methylated in most hematopoietic neoplasms. Cancer Res 1996 56:973-977

7. Qian J, Wang YL, Lin J, Yao DM, Xu WR, Wu CY: Aberrant methylation of the death-associated protein kinase 1 (DAPK1) CpG inland in chronic myeloid leukemia. Eur J Haemato/ 2009, 82:119-123.

8. Melki JR, Vincent PC, Brown RD, Clark SJ: Hypermethyation of E-cadherin in leukemia. Blood 2000, 95:3208-3213.

9. Herman JG, Civin CI, Issa JP, Collector MI, Skarkis SJ, Baylin SB: Distinct patterns of inactivation of p15INK4B and p16INK4A characterize the major types of hematological malignancies. Cancer Res 1997, 57:837-841

10. Maytin EV, Habener JF: Transcription factors C/EBP alpha, C/EBP beta, and CHOP (Gadd153) expressed during the differentiation program of keratinocytes in vitro and in vivo. J Invest Dermatol 1998, 110:238-246.

11. Tang QQ, Lane MD: Role of C/EBP homologous protein (CHOP-10) in the programmed activation of CCAAT/enhancer-binding protein-beta during adipogenesis. Proc Natl Acad Sci USA 2000, 97:12446-12450.

12. Pereira RC, Delany AM, Canalis E: CCAAT/enhancer binding protein homologous protein (DDIT3) induces osteoblastic cell differentiation. Endocrinology 2004, 145:1952-1960.

13. Coutts M, Cui K, Davis KL, Keutzer JC, Sytkowski AJ: Regulated expression and functional role of the transcription factor CHOP (GADD153) in erythroid growth and differentiation. Blood 1999, 93:3369-3378.

14. Friedman AD: GADD153/CHOP, a DNA damage-inducible protein, reduced CAAT/enhancer binding protein activities and increased apoptosis in 32D c13 myeloid cells. Cancer Res 1996, 56:3250-3256.
15. Matsumoto M, Minami M, Takeda K, Sakao Y, Akira S: Ectopic expression of CHOP (GADD153) induces apoptosis in M1 myeloblastic leukemia cells. FEBS Lett 1996, 395:143-147.

16. Qian J, Chen Z, Lin J, Wang W, Cen J: Decreased expression of CCAAT/ enhancer binding protein zeta (C/EBPzeta) in patients with different myeloid diseases. Leuk Res 2005, 29:1435-1441.

17. Agrawal S, Hofmann WK, Tidow N, Ehrich M, Boom D van den, Koschmieder S, Berdel WE, Serve H, Müller-Tidow C: The C/EBPS tumor suppressor is silenced by hypermethylation in acute myeloid leukemia. Blood 2007, 109:3895-3905.

18. Hackanson B, Bennett KL, Brena RM, Jiang J, Claus R, Chen SS, BlagitkoDorfs N, Maharry K, Whitman SP, Schmittgen TD, Lübbert M, Marcucci G, Bloomfield CD, Plass C: Epigenetic modification of CCAAT/enhancer binding protein A expression in acute myeloid leukemia. Cancer Res 2008, 68:3142-3151.

19. Jost E, do ON, Wilop S, Herman JG, Osieka R, Galm O: Aberrant DNA methylation of the transcription factor C/EBPa in acute myelogenous leukemia. Leuk Res 2009, 33:443-449.

20. Herman JG, Graff JR, Myöhänen S, Nelkin BD, Baylin SB: Methylationspecific PCR: a novel PCR assay for methylation status of CpG islands. Proc Natl Acad Sci USA 1996, 93:9821-9826.

doi: 10.1186/1756-9966-29-54

Cite this article as: Wang et al., Methylation status of DDIT3 gene in Chronic Myeloid Leukemia Journal of Experimental \& Clinical Cancer Research 2010 $29 \cdot 54$

\section{Submit your next manuscript to BioMed Central} and take full advantage of:

- Convenient online submission

- Thorough peer review

- No space constraints or color figure charges

- Immediate publication on acceptance

- Inclusion in PubMed, CAS, Scopus and Google Scholar

- Research which is freely available for redistribution 